ЧЖАН ВЕЙ

\title{
ПІДГОТОВКА ВОКАЛІСТІВ У МУЗИЧНИХ ЗАКЛАДАХ ВИЩОЇ ОСВІТИ КНР
}

\author{
(C) Чжан Вей, 2019 \\ https://orcid.org/0000-0002-4132-8198 \\ http://doi.org/10.34142/2312-2471.2019.62.22
}

У статті розкрито основні підходи до підготовки здобувачів освіти вокальної справи в музичних закладах вищої освіти Китайської Народної Республіки (КНР). Розглянуто історичний контекст підготовки здобувачів освіти вокального мистецтва. У дослідженні виділено три провідних заклади вищої музичної освіти Китайської Народної Республіки: Китайська консерваторія, Центральна консерваторія, Шанхайська консерваторія. Аналіз системи підготовки вокалістів у ичих провідних навчальних закладах дозволяє більш чітко зрозуміти основні підходи та шляхи у становленні майбутніх майстрів вокальної справи. Виділено основні принщипи підготовки здобувачів освіти у Китайській консерваторії: «наслідування стародавньої китайської цивілізації», «розвиток рими китайської культури», «розвиток талантів та здібностей для краӥни» та «бути колискою китайських музикантів». Розкрито особливості навчального прочесу в Китайській консерваторії. Навчальний процес забезпечено за останнім словом техніки цифрровими засобами навчання. Аудиторії обладнані як сучасними, так $і$ класичними інструментами. Особлива увага приділясться використанню традииійних китайських технік співу. Освітній прочес у Центральній консерваторії організований на основі синтезу підвищення якості виховання талановитих студентів за рахунок збільшення індивідуальних занять та колективних форм музикування: хор, оркестр, камерний ансамбль. Особлива увага приділяється виконавчій практиці, щзо дозволяє студентам легше адаптуватися після закінчення консерваторії до різних видів професійної діяльності. В освітньому процесі Шанхайської консерваторії у навчанні прийняті принципи поступовості в освоєнні матеріалу, використовуються форми індивідуальних занять. В оволодінні методом співу використовується науковий підхід, студенти повинні розуміти основні принципи співу.

Ключові слова: вокал, здобувачі вищої музичної освіти, консерваторії, освітні принщипи, традииіï.

\section{Zhang Wei. Vocalists' Training in Musical Institutions of Higher Education in PRC}

The article examines the main approaches to the training of vocal education students in higher education music institutions of the People's Republic of China (PRC). The historical context of vocal art education training is considered. The study identified three leading institutions of higher music education in the People's 
Republic of China: China Conservatory of Music, Central Conservatory of Music and Shanghai Conservatory of Music. The analysis of the vocal training system in these leading educational institutions allows the clearer understanding of the main approaches and ways in future masters' development of vocal work. The main principles of training students at the China Conservatory of Music are highlighted: "inheritance of ancient Chinese civilization", "development of rhyme in Chinese culture", "development of talents and abilities for the country" and "to be the cradle of Chinese musicians". The features of the educational process at the China Conservatory of Music are revealed. The educational process is provided with the latest technology with all digital teaching tools. The auditoriums are equipped with both modern and classical instruments. The particular attention is paid to the use of traditional Chinese singing techniques. The educational process at the Central Conservatory of Music is organized on the basis of a synthesis of improving the quality of education of talented students by increasing individual classes and collective forms of music, they are choir, orchestra and chamber ensemble. The particular attention is paid to the executive practice, which allowed students adapt after graduation to more easily to different types of professional activities. In the educational process of the Shanghai Conservatory of Music the principles of gradualness in the development of the materials are adopted, the forms of individual lessons are used. A scientific approach in mastering the singing method is used, students must understand the basic singing principles.

Key words: vocal, students in higher music education, conservatories, educational principles, traditions.

Постановка проблеми. У Китаї в XXI столітті вокальне мистецтво переживає особливий період розвитку. Керуючись законами діалектики, можна констатувати, що за минуле століття відбулося багато змін, які привели до якісних накопичень, з якими китайське музично-вокальне мистецтво яскраво заявило про себе в просторі світової музичної культури. Сучасна стилістика китайського співу виявляе нові ресурси вокального мистецтва, які вже не сприймаються як екзотичні, але свідчать про якісні сторони нового мистецтва простору в галузі світової вокальної культури, яка генерує у собі китайські традиції та новітні підходи до їі реалізації.

При цьому в Китайській Народній Республіці (КНР) все ще йде активний процес формування школи співу через надання їй академічного статусу. Ці перетворення сприяють подальшому розвитку вокального мистецтва та підсилюють процеси інтеграції китайської вокальної традиції 3 кращим світовим досвідом.

Аналіз останніх досліджень і публікацій. Проблемі навчання вокалістів у закладах вищої освіти КНР присвячено ряд досліджень. Систему музичної освіти в КНР досліджував Хуан Сяньюй [5], Ян Бо [11]. Інтеграцію європейської та китайської традиції вокального співу досліджував Сун Яньин [4]. Проблему підготовки вокалістів розглядали Чжан Лу [7], Чжоу Сяоянь [8], 
Чэнь Ин [9], Яо Вэй [12], Л. Ярославцева [13]. Методичним питанням підготовки вокалістів присвятив свої праці Цзинь Телинь [6].

Виділення невирішених раніше частин загальної проблеми. Питання розкриття системи підготовки вокалістів у закладах вищої освіти КНР не мають достатньої представленості в науковій літературі України.

Метою статті $\epsilon$ розкриття системи підготовки вокалістів у закладах вищої освіти КНР.

Виклад основного матеріалу. Вокальна освіта Китаю сягає багатьох століть і направлена на підготовку висококультурних та освічених майстрів своєї справи. Сучасний стан розвитку вокальної освіти в КНР характеризується поєднанням західної вокальної школи та традиційної китайської. Політика економічних реформ започаткована в 70 -х роках $\mathrm{XX}$ століття покликана була «відкрити» Китай світу 3 його надзвичайною історією культурою та економічними можливостями.

Ці трансформаційні процеси відобразилися й на процесі підготовки митців вокальної справи. Наприкінці 90 -х років у КНР було запроваджено загальну реформу освіти, яка не оминула і сферу мистецько-культурної освіти. У ході реформи було переглянуто існуючі педагогічні підходи та програми 3 підготовки здобувачів освіти [10].

На сьогодні в КНР існує багато закладів вищої музичної освіти, але серед них виділяються три найбільш потужних центри 3 підготовки здобувачів освіти вокального напряму освіти:

- Китайська консерваторія [1];

- Центральна консерваторія [2];

- Шанхайська консерваторія [3].

Аналіз системи підготовки вокалістів у цих провідних навчальних закладах дозволить більш чітко зрозуміти основні підходи та шляхи у становленні майбутніх майстрів вокальної справи.

Почнемо з Китайської консерваторії (China Conservatory of Music), яка була заснована у 1964 році. Вона визначає своїми цілями виховати та навчити особистість, яка відкрита до дослідження, створення (творіння), виконання й освіти. Ця особистість керується принципами «наслідування стародавньої китайської цивілізації», «розвитку рими китайської культури», «розвитку талантів та здібностей для країни» та «бути колискою китайських музикантів». Китайська консерваторія в даний час $є$ єдиною в країні, де здійснюється підготовка музикантів, які виконують національну музику, i ведуться дослідження цього напряму музичного мистецтва.

Сьогодні підготовку фахівців тут здійснюють 10 факультетів: Arts Management Department; Chinese Instruments Department; Composition Department; Conducting Department; Music Education Department; Music Technology Department; Musicology Department; Orchestral Instruments Department; Piano Department; Voice and Opera Department. Консерваторія має право присвоювати вчені ступені магістра мистецтв і доктора музикознавства. На іiі базі створена система безперервної освіти завдяки центральній музичній 
школі. За їі підтримки формується багатоступенева система народної музичної освіти та наукової діяльності. У Китайській консерваторії працюють відомі викладачі та дослідники.

За п’ятдесят п’ять років свого існування Китайська консерваторія виховала понад п'ять тисяч відомих музичних виконавців, у тому числі й міжнародного значення: сопрано Пен Ліюуань, тенор Яань Вейвень, сопрано Тан Цзин та інші [10]. До навчального плану факультету сольного співу та оперної підготовки (Voice and Opera Department) входять такі основні групи предметів:

- історія та теорія китайської музики (народні пісні, китайська музична драма, естрадний жанр з співом і розповіддю, народні інструменти тощо) для студентів всіх факультетів, до того ж методика викладання цих дисциплін заснована на поєднанні теорії і практики (прослуховування та перегляду аудіота відеозаписів, вивчення і виконання характерних творів);

- спеціальні дисципліни вокального факультету головним чином представляють собою національний спів, студенти співають народні пісні, арії 3 китайської музичної драми та народні пісні на основі бельканто;

- загальнопрофесійні дисципліни спрямовані на підготовку до освоєння традиційного методу співу, вдосконалення артикуляції та фізичного розвитку (танці) [1].

На сьогодні Китайська консерваторія - це потужний хаб надання музичних освітніх послуг та досліджень у галузі народного музичного мистецтва. Навчальний процес забезпечений за останнім словом техніки усіма цифровими засобами навчання. Аудиторії обладнані як сучасними, так i класичними інструментами. Особлива увага приділяється використанню традиційних китайських технік співу.

Далі розглянемо Центральну консерваторію (Central Conservatory of Music), яка була заснована 1949 року. Це спеціалізований китайський заклад вищої освіти (ЗВО) для виховання музичних професіоналів високого рівня, адже в Китаї єдина академія мистецтв, що занесена до числа провідних національних університетів, що підтримуються державним «Проектом 211» («Project 211»).

Організаційно Центральна консерваторія складається 38 факультетів: Composition Department, Musicology Department, Conducting Department, Piano Department, Orchestral Instruments Department, Traditional Chinese Instruments Department, Voice and Opera Department, Music AI and Information Technology Department.

Крім того, до складу консерваторії водять Інститут музичної освіти, Центр роботи зі скрипкою, Середня школа при консерваторії, Сучасний музичний коледж дистанційного навчання, Коледж неперервної освіти та Інститут музикології. Центральна консерваторія виступає як ключова національна база досліджень гуманітарних та соціальних наук, призначена Міністерством Освіта Китаю [2]. 
Освітній процес у Центральній консерваторії організований на основі синтезу підвищення якості виховання талановитих студентів за рахунок збільшення індивідуальних занять та колективних форм музикування - хор, оркестр, камерний ансамбль. Особлива увага приділяється виконавчій практиці, що дозволяє студентам легше адаптуватися після закінчення консерваторії до різних видів професійної діяльності. Термін навчання становить 5 років на факультетах композиції, музикознавства, диригування й оперного співу та 4 роки на інших факультетах.

На факультеті Voice and Opera велика увага приділяється розвитку практичних професійних навичок студентів, тому що здобувачі освіти беруть участь у підготовці та виконанні великої кількості опер. У репертуарний список входять такі твори, як «Жалкувати про минуле» Ши Гуаннань, «Так чинять усі», «Весілля Фігаро», «Милосердя Тита», «Чарівна флейта» Моцарта, «Богема», «Чіо-Чіо-сан» Пуччіні, «Травіата», «Ріголетто» Верді, «Кармен» Бізе, «Євгеній Онєгін» Чайковського тощо. 321 квітня по 27 квітня 2013 року в Центральній консерваторії проводився Пекінський міжнародний музичний фестиваль бароко, який отримав позитивну оцінку міжнародних експертів, які взяли участь у фестивалі.

Наприклад, відомий австрійський скрипаль i диригент, фахівець 3 барокової музики Лоренц Дуфтшмідт, німецький органіст і диригент Кей Йоханнс, музиканти Державної академічної капели Санкт-Петербурга, лауреати міжнародних конкурсів В. Шляпніков (орган), Е. Яскунова (сопрано) залишили високі відгуки в пресі. Успіх фестивалю започаткував традицію його щорічного проведення [10].

Третьою у вищезазначеному списку, але не за своїм значенням, була Шанхайська консерваторія (Shanghai Conservatory of Music). Цей заклад вищої музичної освіти має давню історію та став альма-матер для багатьох визначних митців музичної та вокальної справи. Зазначимо, що на момент свого створення у 1927 році Шанхайська консерваторія носила назву Національної консерваторії (National Conservatory of Music) та була першим закладом вищої музичної освіти в Китаї [3].

Шанхайська консерваторія має п'ятнадцять факультетів та приєднану середню школу з початковою секцією. Це перший музичний заклад у Китаї, який поєднує в одній системі початкову, середню та вищу освіту. У числі дисциплін, які викладаються у консерваторії не тільки традиційні, але й нові, в тому числі, засновані на міждисциплінарному підході. Шанхайська консерваторія надзвичайно піклується про викладацький склад. Тут працюють численні китайські та іноземні фахівці. Випускники консерваторії відомі в усьому світі, багато з них працюють у сфері культури та мистецтва, в музичних навчальних закладах та науково-дослідних інститутах. Консерваторія відома як «колиска музикантів» [3].

Навчальний план зі спеціальності «Сольний спів і оперна підготовка» більшою мірою орієнтовані на реалізацію загальнодержавної культурної політики, ніж в двох інших консерваторіях. Так, у якості цілей і завдань 
навчання тут декларується здійсненням освітньої політики комуністичної партії. Відповідно іiі основними принципом є: розвиток китайської народної вокальної традиції, служіння державі та їі інтересам, гармонійне поєднання традиційного та західного стилю виконання.

Підготовка вокалістів передбачає викладання у формі індивідуальних занять дві навчальні години на тиждень та одне заняття 3 концертмейстером. Здобувач освіти зобов'язані взяти участь в трьох концертах у кожному семестрі, де необхідно виконати китайську та закордонну пісню. При необхідності, всі викладачі можуть бути присутніми на заняттях студентів для обміну педагогічним досвідом і підвищення якості викладання.

Студенти третього, четвертого і п'ятого курсів під керівництвом педагога проходять виконавчу практику, яка $\epsilon$ важливим показником їх успішності в процесі отримання необхідних знань та умінь. У навчанні використовуються принципи поступовості в освоєнні матеріалу та форми індивідуальних занять. В оволодінні методом співу використовується науковий підхід, тобто студенти повинні розуміти основні принципи співу. Загалом під час навчання в консерваторії потрібно засвоїти 20 творів (китайські й іноземні вокальні твори та китайські народні пісні). Студент, що не освоїв необхідну кількість репертуару, не допускається до випускного іспиту.

Висновки. Таким чином, констатуємо, що вокальна підготовка здобувачів вищої музичної освіти у ЗВО КНР має визначену структуру, окреслені традиції та свою специфіку в залежності від консерваторії. Важливо відзначити, що в усіх музичних закладах вищої освіти присутні заняття 3 ідеології, тому що китайське суспільство турбується про морально-етичне виховання здобувачів освіти. Кількість таких занять та їх направленість відрізняється у різних закладах.

Підкреслимо загальні відмінності, які $\epsilon$ між консерваторіями, що розглядалися вище. Так, в Центральній консерваторії всі здобувачі музичної освіти факультету вокалу, вивчаючи манеру співу бельканто, освоюють романси й оперні арії італійських, німецьких і французьких композиторів, тому актуальним для них $є$ паралельне вивчення у консерваторії європейських мов та традицій. У Китайській консерваторії основна увага звернена на вокальну підготовку в плані з'єднання європейських і китайських традицій, що підсилює морально-етичну підготовку здобувачів освіти на засадах ідеалів китайського суспільства. Шанхайська консерваторія докладає великих зусиль на практикоорієнтовану діяльність своїх здобувачів та має великі успіхи в галузі концертної діяльності студентів.

У подальших наукових пошуках планується дослідити специфіку підготовки магістрів вокального мистецтва в ЗВО КНР.

\begin{tabular}{ccc} 
1. Офіційний & \multicolumn{1}{c}{ Лimература } \\
http://en.ccmusic.edu.cn/ & Китайська
\end{tabular}


2. Офіційний сайт. Центральна консерваторія. URL: http://en.ccom.edu.cn/

3. Офіційний сайт. Шанхайська консерваторія. URL: https://en.shcmusic.edu.cn/

4. Сун Яньин. Интеграция европейских традиций пения в вокальную школу Китая: дис. ... канд. искусствоведения: 17.00.03. Львов, 2016. 183 с.

5. Хуан Сяньюй. Система музыкального образования в Китае. Вестник Санкт-Петербургского государственного университета культуры и искусств. 2012. №2. 155-159

6. Цзинь Телинь. Вокальная методика. Пекин: Издательство Народная Музыка, 2008. 4. 金铁霖. 《金铁霖声乐教学文集》. 人民音乐出版社.北京.2008.4.M.

7. Чжан Лу. Искусство бельканто на современной китайской сцене. Черты вокальной стилистики Ляо Чанъюн. Культура: открытый формат: сборник научных работ. 2011. 204-208

8. Чжоу Сяоянь. Современные вокальные тенденции: переосмысление вопросов вокальной педагогики. Искусство музыки. Шанхай, 1981, 1-е издание. C. 47-51 周小燕//《当代世界声乐发展趋势给我们的启示--对声乐界若干问题的再认识》。《音乐艺术》. 上海.1981年第1期P.47-51

9. Чэнь Ин. Китайская опера XX - начала XXI века: к проблеме освоения европейского опыта: дис. ...канд. искусствоведения: 17.00.02. Ростов-на-Дону, 2015. $175 \mathrm{c}$.

10. Ян Бо. Динамика развития профессионального сольного пения в Китае : образование, педагогические и исполнительские принципы : диссертация кандидата искусствоведения : 17.00.02. Нижний Новгород, 2016. $186 \mathrm{c}$.

11. Ян Бо. Проблемы становления профессиональной школы пения в Китае периода образования КНР в зеркале музыкальной периодики. Дом Бурганова. Пространство культуры, 2016, №2 (51). 55-61

12. Яо Вэй. Подготовка специалистов вокального искусства в системах высшего музыкального образования Китая и России. Диссертация кандидата педагогических наук. Астрахань, 2015. 196 с.

13. Ярославцева Л. Опера. Певцы. Вокальные школы. Москва. Издательский дом «Золотое руно», 2004. 200 с.

\section{References}

1. Official website (2019). China Conservatory of Music. URL: http://en.ccmusic.edu.cn/

2. Official website (2019). Central Conservatory of Music. URL: http://en.ccom.edu.cn/

3. Official website (2019). Shanghai Conservatory of Music. URL: https://en.shcmusic.edu.cn/ 
4. Song Yanying (2016). Integration of European traditions of singing into the vocal school of China: dissertation of the candidate of art criticism: 17.00.03. Lviv. $183 \mathrm{p}$.

5. Huang Xianyu (2012). Music education system in China. Bulletin of the St. Petersburg State University of Culture and Arts, Vol. 2, 155-159.

6. Jin Tieling (2008). Vocal technique. Beijing: Folk Music Publishing House, 4. 金铁霖 (2008). 《金铁霖 声乐 教学 文集》. 人民 音乐 出版. 北京 .4.M.

7. Zhang Lu (2011). Bel canto art on the contemporary Chinese scene. Liao Changyun's vocal style features. Culture: open format: collection of scientific papers, 204-208.

8. Zhou Xiaoyan (1981). Modern vocal tendencies: rethinking the issues of vocal pedagogy. The art of music. Shanghai, 1st edition. 47-51 周小燕 // 《当代 世界声乐发展趋势 给我们的启示 --- 对声乐界若干问题的再认识》. 《音乐艺术》. 上海. 1981 年 第 1 期. 47-51.

9. Chen Ying (2015). Chinese opera of the XX - early XXI century: on the problem of mastering the European experience: dissertation of the candidate of art criticism: 17.00.02. Rostov-on-Don. 175 p.

10. Yang Bo (2016). Dynamics of development of professional solo singing in China: education, pedagogical and performing principles: dissertation of the candidate of art criticism: 17.00.02. Nizhny Novgorod. $186 \mathrm{p}$.

11. Yang Bo (2016). Problems of the formation of a professional singing school in China during the formation of the PRC in the mirror of musical periodicals. House of Burganov. Space of culture, № 2 (51). 55-61.

12. Yao Wei (2015). Training of vocal specialists in the systems of higher musical education in China and Russia. Dissertation of the candidate of pedagogical sciences. Astrakhan. $196 \mathrm{p}$.

13. Yaroslavtseva L. (2004). Opera. Singers. Vocal schools. Moscow. Publishing house «Golden Fleece». 200 p. 